Anna Jagłowska

Warszawa

\title{
NOWE TRENDY W KULTURZE MUZYCZNEJ NIEMIEC
}

W minionym stuleciu Niemcy były wiodącym ośrodkiem muzyki współczesnej. W Berlinie, Kolonii, a przede wszystkim w Darmstadcie powstały centra, które wspierały idee 'Nowej Muzyki'. Była to nowatorska technika kompozytorska w muzyce, oparta na gamie diatonicznej, która została upowszechniona w Europie przez jej zwolenników ${ }^{1}$.

Pojęcie 'Nowa Muzyka' zostało sformułowane na początku XX wie$\mathrm{ku}$ przez austriackiego kompozytora Arnolda Schönberga. Urodzony w 1874 roku w Wiedniu Schönberg był wybitnym i jednym z najbardziej wpływowych austriackich kompozytorów wczesnych lat XX wieku. Krok w atonalności był początkiem tego, co póżniej zostało nazwane Nową Muzyką ('Neue Musik'). Pierwszym w pełni dodekafonicznym dziełem, czyli stworzonym dzięki nowej technice kompozytorskiej w muzyce współczesnej opartym na rozszerzonej gamie diatonicznej (dwunastotonowa technika odrzucająca tonalność), Schönberga była "Suita fortepianowa”, której premiera odbyła się w 1923 roku. Schönberg był kompozytorem uniwersalnym. W jego utworach można znaleźć szerokie spektrum form od pieśni i muzyki chóralnej, przez utwory na małe zespoły instrumentalne, muzykę kameralną do dzieł symfonicznych².

Muzykolodzy Nową Muzykę określają jako awangardową, modernistyczną, powszechnie nazywają 'nowoczesną', przede wszystkim z racji na likwidację tonalności, która obowiązywała przez stulecia. Pojęcia takie jak 'awangarowy', 'modernistyczny' stosowane były wobec sztuki od końca XIX wieku, ponieważ narastało zdezorientowanie publiczności coraz bardziej indywidualną i często zmieniającą się muzyką, której większość

${ }^{1}$ Myzyka. Kompozytorzy i wykonawcy, prady i kierunki, dzieła, (red.), S. Żurawski, Warszawa 2007, s. 529.

${ }^{2}$ Myzyka. Kompozytorzy i wykonawcy, prady i kierunki, dzieła, (red.), S. Żurawski, Warszawa 2007, s. 706-707. 
słuchaczy nie potrafiła zaakceptować. Zasadniczym argumentem podnoszonym przeciwko nowym utworom była ich dysonansowość ${ }^{3}$. Z muzyką współczesną, która narodziła się dzięki muzyce poważnej, kojarzą się pojęcia oznaczające różne kierunki, techniki i style, takie jak impresjonizm, ekspresjonizm, witalizm, bruityzm, minimalizm, sonoryzm lub muzyka dekafoniczna. Pierwszym postulatem dodekafonii było, że każdy dźwięk z dwunastostopniowej skali powinien być jednakowo uprawniony. Drugi postulat brzmiał, że żaden dźwięk nie powinien być powtórzony, dopóki nie zostaną użyte wszystkie dźwięki skali ${ }^{4}$ Ciąg dźwięków, nazwany przez Schönberga szeregiem, porządkiem lub serią - po niemiecku 'Reihe', nie jest odpowiednikiem tradycyjnie pojmowanej melodii ${ }^{5}$.

Warto podkreślić, że to Wiedeń, stolica muzyki XIX w., był kolebką 'Nowej Muzyki', czyli muzyki współczesnej, a dosłownie muzyki tworzonej współcześnie. W Wiedniu tworzył Schönberg i tu przyciągał młodych awangardzistów, przede wszystkim Albana Berga i Antona Weberna, dla których stał się nauczycielem i mentorem. Uczniem Albana Berga był Theodor Adorno, znaczący teoretyk Nowej Muzyki, który atonalność Schönberga rozumiał jako wyzwolenie muzyki dające możliwość rozwoju muzycznego ${ }^{6}$.

Na początku dwudziestego wieku życie muzyczne w Niemczech było jednak wciąż ukształtowane przez mieszczańskie rozumienie tradycji, odwołującej się przede wszystkim do twórczości Beethovena (1770-1827) i Wagnera (1813-1883). W utworach Richarda Straussa (1864-1949) widziano gwarancje postępu, który miał poprawić pozycję Niemiec jako ‘Musiknation'. Pomimo narastających społecznych sprzeczności oraz napięć w polityce zagranicznej, w obszarze kultury nadal preferowana była harmonia i wiara w przyszłość, również w muzyce. To właśnie Richard Strauss stał się czołową postacią zaawansowanego modernizmu muzycznego. Stosował technikę leitmotywów, wyrafinowaną harmonikę i sztukę instrumentacji ${ }^{7}$. Strauss uważał: „Dlatego precz ze stosowaniem belferskiej estetyki w odniesieniu do dzieł, które należy mierzyć własna miarą; precz z wszelkimi tablicami przykazań, które dawno już zostały rozbite przez wielkich mistrzów; precz z wszelkiego rodzaju najwyższym kapłaństwem, które

${ }^{3}$ Myzyka. Kompozytorzy i wykonawcy, prady i kierunki, dzieła, (red.), S. Żurawski, Warszawa 2007, s. 227.

${ }^{4}$ I. Lindstedt, Dodekafonia i serializm w twórczości kompozytorów polskich, [w:] Kompozytorzy polscy 1918-2000, Gdańsk-Warszawa 2005, s. 234.

${ }_{5}^{5}$ Myzyka. Kompozytorzy i wykonawcy, prady i kierunki, dzieła, (red.), S. Żurawski, Warszawa 2007, s. 707.

${ }^{6}$ Myzyka. Kompozytorzy i wykonawcy, prady i kierunki, dzieła, (red.), S. Żurawski, Warszawa 2007, s. 529.

${ }^{7}$ Myzyka. Kompozytorzy i wykonawcy, prady i kierunki, dzieła, (red.), S. Żurawski, Warszawa 2007, s. 758. 
chce stanąć na drodze pełnemu mocy rozwojowi; precz z wszystkim, co nie może wykazać się innym uzasadnieniem niż fakt, że istniało już wczoraj"8. Strauss był zdania, że tylko publiczność powinna wydawać opinie dotyczące nowo powstałych dzieł.

Punktem zwrotnym w rozwoju Nowej Muzyki w Niemczech był festiwal Kammermusiktage, który od 1921 roku odbywał się w szwardzwaldzkim miasteczku Donaueschigen. Festiwal ten dość dokładnie oddawał obraz rozwoju Nowej Muzyki w latach dwudziestych w Niemczech - od ekspresjonizmu, poprzez Neue Sachlichkeit (nowa rzeczowość), Gebrauchsmusik (muzyka użytkowa) oraz Angewandte Musik (muzyka stosowana), aż po eksperymenty muzyczne przy wykorzystaniu mechanicznych generatorów dżwięku. „Można było usłyszeć fortepian elektryczny huczący w oktawach, sześciokrotnych trylach, niesamowitych przebiegach i akordach" ${ }^{\prime \prime}$. W tym czasie, a dokładnie w 1925 roku, Arnold Schönberg przybył z Wiednia do Berlina, gdzie kierował mistrzowską klasą kompozycji w Akademie der Künste. W okresie powojennym powstała ważna dla Niemiec istytucja muzyczna, której udało się przetrwać okres nazizmu dzięki międzynarodowej strukturze: Internationale Gesellschaft für Neue Musik. Stowarzyszenie to powstało w 1922 roku. „Była to międzynarodowa sieć stworzona przez ludzi o podobnych zapatrywaniach i dla nich przeznaczona, organizacja dla kompozytorów, wykonawców, krytyków i mecenasów, służąca stworzeniu bazy społecznej dla niezabezpieczonej jeszcze pod względem instytucjonalnym nowej muzyki"10. Jej członkami założycielami byli Bela Bartok (1881-1945), Artur Honegger (1892-1955), Zoltan Kodaly (1882-1967), Darius Milhaud (1892-1974) i kompozytorzy schönbergowskiej szkoły wiedeńskiej, natomiast prezesem założycieli był Richard Strauss.

Kiedy w styczniu 1933 roku na stanowisko Kanclerza Rzeszy został powołany Hitler natychmiast rozpoczęła się masowa ucieczka artystów i intelektualistów. Istniejące dotychczas instytucje muzyczne zostały od razu rozwiązane i zastąpione nowymi. W zakresie kultury reżim narodowosocjalistyczny w pierwszej kolejności usunął wszystko to, co stworzono w zakresie sztuki awangardowej w Republice Weimarskiej. Po przejęciu władzy przez Hitlera, Schönberg opuścił Berlin, wyjeżdżając do Stanów Zjednoczonych, a wraz z nim wielu znaczących artystów. Wraz z zakończeniem wojny zrodziła się nadzieja na lepszą przyszłość.

${ }^{8}$ M. Nyffeler, Droga ku przepaści. Rozwój nowej muzyki w Niemczech w latach 1900-1945, [w:] Nowa muzyka niemiecka, (red.) D. Cichy, Kraków 2010, s. 10.

${ }_{9}$ M. Nyffeler, Droga ku przepaści. Rozwój nowej muzyki w Niemczech w latach 1900-1945, [w:] Nowa muzyka niemiecka, (red.) D. Cichy, Kraków 2010, s. 20.

${ }^{10}$ M. Nyffeler, Droga ku przepaści. Rozwój nowej muzyki w Niemczech w latach 1900-1945, [w:] Nowa muzyka niemiecka, (red.) D. Cichy, Kraków 2010, s. 19. 
Do jednych z najwybitniejszych i najbardziej wpływowych osobowości kompozytorskich Niemiec należą dziś Wolfgang Rihm, Markus Hechtle oraz Martin Schüttler.

Kompozytor Wolfgang Rihm, którego dorobek liczy już ponad 400 utworów, wkroczył na scenę muzyki współczesnej w 1970 roku w Darmstadcie, kiedy umieścił swoje pierwsze zgłoszenie na Internationale Ferienkurse für Neue Musik, zawierające w swoim programie zarówno nauczanie kompozycji jak i interpretacji muzyki, a także premiery nowych prac. Otrzymanie prestiżowej nagrody Kranichsteiner Musikpreis w roku 1978 pokazało, że Wolfgang Rihm jest kompozytorem wysokiej klasy $^{11}$. Muzyka Rihma, która została opatrzona etykietą 'Neue Einfach-heit' (nowa prostota), łączy w muzyce i słowie procesy rozwoju kompozytorskiego i estetycznego. Z nową prostotą wiązano nie tylko Rihma, ale także innych wiodących przedstawicieli kompozytorów awangardowych, jak np. Jensa-Petera Ostendorfa, Helmuta Cromma i Detleva Müllera Siemensa. Cechami charakterystycznymi 'nowej prostoty' były decyzja przeciw czemuś, decyzja na coś oraz traktowanie tych decyzji jako wytycznej dla wszystkich oraz uznanie, że subiektywność kompozytora jest jedyną miarodajną instancją kompozytorską i estetyczną. „W myśleniu kompozytorskim Rihma muzyka z uważającym się za tworzący podmiot kompozytorem buduje jedność przeciwko rozdzielaniu sztuki i życia"12. Rihm podkreśla, że „,...] u początku odkrywania znajduje się ocieniający wszystko błysk, to nie mogą być to regulaminy, reguły, które chcą być spełnione, lecz jestem tego pewien, musi to być stan samej natury, z którego sztuka dąży do powstania"13. To intuicja, spontaniczność i oryginalność, które są charakterystycznymi oznakami myślenia muzycznego Rihma powodują, że podstawową zasadą komponowania staje się jego aura i atmosfera. Rihm uważa, że „wyraża się to w gorączkowym szukaniu, za pomocą którego próbuję odnaleźć rytm w codzienności"14. Na pytanie, co oznacza dla Rihma komponowanie, odpowiada: „Oznacza ono, by pozwolić zatrzymać się w życiu w jego momentach kryzysowych, sformułować je i znaleźć swoiste spełnienie w przekazywaniu tego zakrzepłego czasu ży$\mathrm{cia}^{\prime 15}$. Rihm pozostaje wierny wcześnie sformułowanej estetyce inspiracji,

${ }^{11}$ Myzyka. Kompozytorzy i wykonawcy, prady i kierunki, dzieła, (red.), S. Żurawski, Warszawa 2007, s. 645.

12 A. Heidenreich, Przeciwko szarej, klinicznej poprawności. Kompozytor Wolfgang Rihm, [w:] Nowa muzyka niemiecka, (red.) D. Cichy, Kraków 2010, s. 257.

13 A. Heidenreich, Przeciwko szarej, klinicznej poprawności. Kompozytor Wolfgang Rihm, [w:] Nowa muzyka niemiecka, (red.) D. Cichy, Kraków 2010, s. 260.

14 A. Heidenreich, Przeciwko szarej, klinicznej poprawności. Kompozytor Wolfgang Rihm, [w:] Nowa muzyka niemiecka, (red.) D. Cichy, Kraków 2010, s. 262.

15 A. Heidenreich, Przeciwko szarej, klinicznej poprawności. Kompozytor Wolfgang Rihm, [w:] Nowa muzyka niemiecka, (red.) D. Cichy, Kraków 2010, s. 263. 
a jego credo brzmi: „Chcę poruszać i być poruszony, w muzyce wszystko jest patetyczne"16.

Dla urodzonego w roku 1967 Markusa Hechtle, ucznia Rihma, najistotniejszym motywem pracy kompozytorskiej jest "całkowite poddanie się własnym doświadczeniom i przejęcie odpowiedzialności za to, co w ten sposób powstanie, przy jednoczesnym odrzuceniu bezpieczeństwa, które gwarantuje tradycja”. Hechtle wyznaje, że "komponowanie to dla mnie bardzo męczący proces. Wiąże się to z tym, że jest on dla mnie właściwie pozbawiony elementu zabawy. Czasem życzyłbym sobie swobodnego podejścia. Jak dotąd nie udało mi się jednak takiego osiągnąć. Wynika to, jak sądzę, z faktu, że w przypadku każdego utworu chodzi mi o to, by najpierw coś pokonać, uporać sie z materiałem i odnaleźć interesujące mnie dźwieki"17. Dwa podstawowe stany charakteryzują jego pracę kompozytorską. Z jednej strony „niezdolność widzenia tego, przesłania własne spojrzenie”, a z drugiej „wysiłek, by mimo tego coś zobaczyć"18. Hechtle jest zdania, że „komponowanie składa się w pierwszym rzędzie z pytań, które pojawiają się we mnie. Jeśli chcę dostarczyć gotowy utwór, muszę na te pytania tymczasowo odpowiedzieć. Są to jednak tylko tymczasowe odpowiedzi, a nie sformułowane mądrości. Toteż pozostają one przeczuciami, nawet jeśli ostatecznie są czarne na białym zapisane papierze. $\mathrm{Na}$ końcu brzmi to, co brzmi: kompozycja”"19. „Blinder Fleck” („Ślepa plama”) to tytuł utworu kameralnego, który Hechtle ukończył w 2005 roku. Utwór ten jest ważny dla jego zrozumienia komponowania jako poszukiwania tego, co przed kompozytorem ukryte, co utracone. Sam Hechtle nazywa to komponowaniem pytającym, które niesie za sobą muzykę pytającą. Muzyka ta często bywa niejasna, trudna w zrozumieniu. Hechtle zwraca uwagę na „ślepe plamy” w muzyce, które podczas tego rodzaju komponowania się pojawiają ${ }^{20}$. „W zasadzie każdy z moich utworów mógłby nosić ten tytuł, gdyż w pracy zawsze chodzi o wytropienie rzeczy, o których nie ma się pojęcia, które nie maja jeszcze twarzy, co do których człowiek nie wie dokładnie, o co chodzi, przeczucia, nic innego niż pożądanie nad przeczuciami. Charakteryzuje to całą moją pracę"21. Eksperymentowanie

${ }^{16}$ W. Rihm, Ins eigene Fleisch, [w:] Neue Zeitschrift für Musik, Leipzig 1979, nr 140, s. 8.

${ }_{17}$ M. Rebhahn, Ślepe plamy. Kompozytor Markus Hechtle, [w:] Nowa muzyka niemiecka, (red.) D. Cichy, Kraków 2010, s. 295.

${ }_{18}$ M. Rebhahn, Ślepe plamy. Kompozytor Markus Hechtle, [w:] Nowa muzyka niemiecka, (red.) D. Cichy, Kraków 2010, s. 295.

${ }_{19}$ M. Rebhahn, Ślepe plamy. Kompozytor Markus Hechtle, [w:] Nowa muzyka niemiecka, (red.) D. Cichy, Kraków 2010, s. 295.

${ }^{20} \mathrm{H}$. Ehrler, Immer ganz von vorn anfangen, http://projekte.musikrat.de/index. php?id=5904, 7.12.2012.

${ }^{21}$ M. Rebhahn, Ślepe plamy. Kompozytor Markus Hechtle, [w:] Nowa muzyka niemiecka, (red.) D. Cichy, Kraków 2010, s. 296. 
z czasem, „wytrzymywanie czasu”, „rozedrganie czasu” Hechtle opisuje nie tylko jako jedną z reguł swojej pracy kompozytorskiej, ale także jako doświadczenie egzystencjalne. Jednak to właśnie muzyka pozwala to przeżycie w pewien sposób ukształtować i przekazać. W swoich kompozycjach Hechtle poświęca uwagę funkcji muzyki jako sztuki w czasie, związanej z tym, co przejściowe i nieustannie przemijające ${ }^{22}$. „Muzyka stwarza okazję, by poczuć czas, postęp czasu. Znamy to wszyscy w sposobie, w jaki odbieramy muzykę, w jaki przeżywamy najrozmaitszą muzykę. Istnieje muzyka, która szybko mija w czasie, jest też taka, przy której czas się dłuży. W idealnym wypadku przemijanie czasu można postrzegać jako normalny stan fizyczny. I to właśnie interesuje mnie w muzyce"23.

„Sätze mit Pausen” (,Zdania z pauzami”) jest utworem na klarnet, gitarę basową, altówkę, wiolonczelę i kontrabas, który powstał w 2005 roku. Hechtle w tym dziele nie tylko „komponuje instrumenty, ale też przepływ czasu, uznając go za miarodajną strukturę ostatecznego ukształtowania utworu”. Kompozytor podkreśla, że w utworze „Sätze mit Pausen” zajmuję postawę narracyjną. Poruszam się od punktu do punktu i daję sobie na to dużo czasu. Można powiedzieć, że opowiadam muzykę, pozwalam jej nadejść. A gdy już nadejdzie, zatrzymuję się i ponownie pozwalam jej nadejść, obserwując, w którą stronę się rozwinie"24.

Kolejnym utworem Hechtle, o którym warto wspomnieć, jest "Still” do wiersza włoskiego liryka Giacomoa Leopardiego. Powstała w 2003 roku kompozycja łączy wiele elementów: pieśniowe partie wokalne, tęskne melodie, a na końcu tango. „W 'Still' próbowałem udźwiękowić tekst, i to całkiem w dosłownym sensie: słowo po słowie, sytuacja po sytuacji. Nie chodziło mi o 'skakanie' po tekście, o formę zabawy, lecz o to, by rzeczywiście zdanie po zdaniu, ustęp po ustępie 'coś mu wydrzeć'. Podczas tej pracy kierowałem się maksymą: w każdym momencie wszystko jest możliwe! Było to żądanie, jakie skierowałem do samego siebie. Stale zamierzać rozpocząć coś nowego, zawsze móc zmienić perspektywę"25.

Jednym z najmłodszych kompozytorów niemieckich jest Martin Schüttler. Urodzony w 1974 roku w Kassel, a dziś mieszkający w Berlinie kompozytor wprowadził nowe pojęcie na scenę Nowej Muzyki. Jest nim ‘Diesseitigkeit' (zwrócenie ku światu, życiu doczesnemu, ziemski

${ }^{22}$ S. Laurentius, Markus Hechtle, http://www.munzinger.de/search/kdg/Markus+Hechtle/802.html 4.12.2012.

${ }^{23}$ M. Rebhahn, Ślepe plamy. Kompozytor Markus Hechtle, [w:] Nowa muzyka niemiecka, (red.) D. Cichy, Kraków 2010, s. 296.

${ }_{24}$ M. Rebhahn, Ślepe plamy. Kompozytor Markus Hechtle, [w:] Nowa muzyka niemiecka, (red.) D. Cichy, Kraków 2010, s. 297.

${ }^{25}$ M. Rebhahn, Ślepe plamy. Kompozytor Markus Hechtle, [w:] Nowa muzyka niemiecka, (red.) D. Cichy, Kraków 2010, s. 298. 
charakter). Interpretować to należy jako świadome umieszczenie dzieła sztuki w 'zwyczajnej' teraźniejszości ${ }^{26}$.

Według Schüttlera większość dzisiejszych dzieł powstaje poprzez obcowanie kompozytorów z rzeczywistością instrumentalną i osobistą. Wybór środków muzycznych jest przy tym zupełnie swobodny i waha się pomiędzy tradycyjnym zastosowaniem instrumentów, zaawansowanymi technikami gry a nowoczesną elektroniką. Schüttler jest zdania, że subiektywność kompozytora zawarta jest w tożsamości samej kompozycji, czyli $\mathrm{w}$ specyficznym rozplanowaniu $\mathrm{w}$ czasie, ukształtowaniu instrumentalnym i postaci brzmieniowej. Są to trzy filary kompozytorskiego indywidualizmu, na których opiera się dzisiejsza subiektywność27. Jej doskonałym przykładem jest w dalszym ciągu twórczość Wolfganga Rihma, Markus Hechtle oraz najbardziej współczesnego kompozytora Martina Schüttlera. Sam kompozytor rozumie to w następujący sposób: „Chodzi mi o to, żeby opuścić osobisty kompozytorski kosmos i pójść w kierunku, gdzie muzyka zwraca się ku światu. Co nas otacza pod względem dźwiękowym? Na czym polega akustyczna rzeczywistość, w której się zanurzam, kiedy wychodzę na ulicę? To interesuje mnie najbardziej i jest mi to emocjonalnie bliższe, niż odosobnione istnienie w świecie wewnętrznym" ${ }^{28}$. Schüttler ubolewa nad faktem, iż nie ma możliwości stworzenia idealnych warunków dla swojej pracy kompozytorskiej, ponieważ znajduje się w sieci żądań i konwencji, które w znacznym stopniu marginalizują fakt, że jego działalność ma funkcję wykraczającą poza reguły 'pracy artystycznej'. Od roku 2004 Schüttler pracuje nad cyklem „Schöner Leben” („Piękniej żyć”), który uważa za model, który podkreśla jego niezależność. „Utwory cyklu 'Schöner Leben' powstają, ponieważ chce je pisać, ponieważ zwracają się one do interpretatorów, których cenię i z którymi chciałbym pracować. O tyle ta muzyka przyjmuje wyobrażenie o tym, na jakich warunkach chcę pracować" 29 . Metodą Schüttlera jest posługuje się nieudoskonaloną dźwiękowością, która w efekcie ma przynieść działanie prostych, zwyczajnych materiałów. „W cyklu „Schöner Leben” na fortepian i elektronikę zastępuję proste brzmienie fortepianu przez grubsze i bardziej wielowarstwowe ramy. Nie wychodzi się już automatycznie z założenia, że dźwięki fortepianu rozbrzmiewają, ponieważ utwór napisany jest na

${ }^{26}$ M. Rebhahn, Piękniej żyć. Kompozytor Matrin Schüttler, [w:] Nowa muzyka niemiecka, (red.) D. Cichy, Kraków, 2010, s. 303.

${ }^{27}$ P. Hübner, Und vorm Einschlafen noch ein Bier, http://magazin.klassik.com/reviews/ reviews.cfm?TASK=REVIEW\&RECID=16950\&REID=10985, 27.12.2012.

${ }^{28}$ M. Rebhahn, Piękniej żyć. Kompozytor Matrin Schüttler, [w:] Nowa muzyka niemiecka, (red.) D. Cichy, Kraków, 2010, s. 303.

${ }_{29}$ M. Rebhahn, Piękniej żyć. Kompozytor Matrin Schüttler, [w:] Nowa muzyka niemiecka, (red.) D. Cichy, Kraków, 2010, s. 305. 
fortepian. Zamiast tego grupuję wokół tej zasady, aby komponować utwór na fortepian, inne materiały, jak na przykład folię aluminiową, tercję, głośnik, wzmocnienie. Fortepian staje się elementem, ale już nie dominuje nad resztą"30. Schüttler stanowczo sprzeciwia się fachowej znajomości zastosowania materiałów w muzyce oraz każdej formie podniosłości. Swoje zadanie kompozytorskie rozumie jako poszukiwanie artystycznego dostępu do rzeczywistości, dzięki której muzyka, elementy akustyczne znajdą miejsce we współczesnym społeczeństwie. Schüttler jest zdania, że najpiękniejszą muzykę pisze samo życie ${ }^{31}$.

Nie należy jednak zapominać, że muzyka współczesna wciąż ewoluuje, ciągle są tworzone jej nowe odłamy i rodzaje. Należy dodać, że muzyka niemiecka jest do dnia dzisiejszego nie tylko przedmiotem dyscyplin naukowych, ale też przedmiotem refleksji muzykologii. Współczesna muzykologia niemiecka reprezentuje wysoki poziom naukowy, o czym świadczy m.in. pięć instytutów muzykologii w Berlinie oraz wiele katedr muzykologii na uniwersytetach $\mathrm{w}$ innych miastach niemieckich.

\section{Zusammenfassung}

Berlin, Köln und vor allem Darmstadt waren die Zentren, die die Idee der Neuen Musik unterstützten. Schönberg, einer der einflussreichsten Komponisten des frühen 20. Jahrhundert, war die zentrale Figur in der Entwicklung der Zwölftontechnik, einer neuen Kompositionstechnik, die von den Komponisten der Neuen Musik aufgegriffen wurde und von den Künstlern im 21. Jahrhundert fortgesetzt wird. In dem Beitrag wird der Versuch unternommen, die Bedeutung der Stile und der kompositorischen Techniken der Neuen Musik in enger Verbindung mit der deutschen Kultur des 20. und 21. Jahrhundert darzustellen.

${ }^{30}$ M. Rebhahn, Piękniej żyć. Kompozytor Matrin Schüttler, [w:] Nowa muzyka niemiecka, (red.) D. Cichy, Kraków, 2010, s. 305.

31 P.Hübner, Und vorm Einschlafen noch ein Bier, http://magazin.klassik.com/reviews/ reviews.cfm?TASK=REVIEW\&RECID=16950\&REID=10985, 27.12.2012. 